\title{
Article/Artigo
}

\section{Antimicrobial resistance and investigation of the molecular epidemiology of Listeria monocytogenes in dairy products}

\author{
A resistência antimicrobiana e investigação de epidemiologia molecular de Listeria monocytogenes \\ em produtos lácteos
}

\author{
Fernanda De Nes ${ }^{1}$, Gustavo Pelicioli Riboldi ${ }^{2}$, Ana Paula Guedes Frazzon ${ }^{3}$, Pedro Alves d'Azevedo ${ }^{4}$ \\ and Jeverson Frazzon ${ }^{1,2}$
}

\begin{abstract}
Introduction: Listeria monocytogenes is a ubiquitous microorganism in nature and is responsible for listeriosis, an infectious disease caused by consumption of contaminated food. Methods: Molecular characterization was performed on 19 strains of Listeria monocytogenes (serovars 1/2a, 1/2b, $4 \mathrm{~b}$ and 4c), isolated from dairy products in Rio Grande do Sul, Brazil. The molecular techniques applied were random amplification of polymorphic DNA and restriction enzyme analysis. In addition to the molecular analysis, the antimicrobial resistance profile was determined. Results: The strains studied showed a low degree of diversity. In relation to the antimicrobial resistance profile of those microorganisms from the samples analyzed, all of them were susceptible to the antimicrobials tested. Conclusions: The molecular techniques that were used presented good discriminatory power for the strains studied. Furthermore, all of the samples that were analyzed were susceptible to the antimicrobials tested.
\end{abstract}

Key-words: Listeria monocytogenes. PCR-REA. RAPD. Dairy products.

\section{RESUMO}

Introdução: Listeria monocytogenes é um microrganismo que se encontra disseminado na natureza, sendo responsável por causar listeriose, uma doença infecciosa causada pelo consumo de alimentos contaminados. Métodos: A análise molecular de 19 linhagens de Listeria monocytogenes, sorovares $1 / 2 \mathrm{a}, 1 / 2 \mathrm{~b}, 4 \mathrm{~b}, 4 \mathrm{c}$, isoladas de produtos lácteos do Rio Grande do Sul, Brasil. As técnicas moleculares aplicadas foram: Amplificação Randômica do DNA Polimórfico e Análise por Enzimas de Restrição. Além da análise molecular foi realizado o perfil de resistência antimicrobiana. Resultados: As linhagens estudadas mostraram baixo grau de diversidade, em relação ao perfil de resistência antimicrobiana desses microrganismos das amostras analisadas todas foram susceptíveis aos antimicrobianos testados. Conclusões: As técnicas moleculares estudadas apresentaram um bom poder de discriminação para as linhagens estudadas. Além disso, todas as amostras analisadas foram susceptíveis aos antimicrobianos analisados.

Palavras-chaves: Listeria monocytogenes. PCR-REA. RAPD. Produtos lácteos.

1. Graduate Program in Food Science and Technology, Federal University of Rio Grande do Sul, Porto Alegre, RS, Brazil. 2. Biotechnology Center, Federal University of Rio Grande do Sul, Porto Alegre, RS, Brazil. 3. Department of Microbiology, Federal University of Rio Grande do Sul, Porto Alegre, RS, Brazil. 4. Department of Microbiology, Federal Foundation of Medical Sciences of Porto Alegre, RS, Brazil. Address to: Prof. Jeverson Frazzon. ICTA/UFRGS. Av. Bento Gonçalves 9500, Prédio 42212/Sala 205, Campus do Vale, Bairro Agronomia, 91501-970 Porto Alegre, RS, Brasil.

Phone: 5551 3308-6072; Fax: +55 $513308-7309$

e-mail: jeverson.frazzon@ufrgs.br

Received in 11/11/2009

Accepted in 05/03/2010

\section{INTRODUCTION}

The genus Listeria is formed by six species, among which Listeria monocytogenes is known as one of the main pathogenic speciesinhuman beings. They consistof Grampositive rods that are capable of growing under adverse conditions such as low temperatures, acidic $\mathrm{pH}$, high salt concentrations and the procedures that are applied by the food industry to halt the growth of pathogenic microorganisms. Due to their ubiquitous nature, these bacteriaare constantlyisolatedfrom decomposingmaterial, soil and water, and in this way, they can contaminate raw foods through cross-contamination ${ }^{1}$.

In general, most strains of L. monocytogenes isolated from clinical samples, food and the environment are susceptible to active antimicrobials against Gram-positive bacteria, and the treatment selected is a combination of ampicillin with an aminoglycoside, normally gentamicin ${ }^{2}$. Although all the 13 serovars of L. monocytogenes are capable of causing listeriosis, nearly $95 \%$ of the infection cases in humans are caused by 3 serotypes: $1 / 2 a, 1 / 2 b$ and $4 \mathrm{~b}$. In Brazil, one study has shown that serovar $1 / 2 \mathrm{a}$ is predominant in dairy products ${ }^{3}$.

The aim of the present study was to determine the genotype profile for L. monocytogenes that is predominant in southern Brazil, using molecular biology tools such as random amplification of polymorphic DNA (RAPD) and restriction endonuclease analysis (PCR-REA), on 19 strains isolated from dairy products. Furthermore, the antimicrobial resistance profile of these microorganisms against several antimicrobials that were tested was observed.

\section{METHODS}

Bacterial strains and DNA extraction

The nineteen strains used in the present study were isolated from dairy products and were provided by the National Agricultural and Livestock-Rearing Laboratory in Porto Alegre (LANAGRO/RS). 
These 19 strains included eight strains of serovar $1 / 2 \mathrm{~b}$ (A32, A33, A34, A35, A36, A37, A38 and A39), eight strains of 4b (A40, A42, A43, A45, A47, A48, A49 and A50), two strains of 1/2a (A55 and A54) and one strain of serovar $4 c$ (A46). The serovars of the strains were determined by the Oswaldo Cruz Institute, Rio de Janeiro, Brazil. ATCC 7645 (serovar 1/2a) and strains isolated in Canada A51 (serovar 4b) and A56 (serovar 1/2a) were used as controls. In order to analyze the morphology and confirm the colony purity, cells were grown in listeria enrichment broth (LEB; Acumedia) for 18 hours at $37^{\circ} \mathrm{C}$ in a shaker and then isolated on solid media (LEB, $1.5 \%$ agar-agar). The cells were stored at $-70^{\circ} \mathrm{C}$ in glycerol. The chromosomal DNA was extracted from the strains as described by Torres et $\mathrm{al}^{4}$.

\section{Antimicrobial susceptibility test}

All antimicrobial susceptibility tests were carried out using the standard disk diffusion method recommended by the NCCLS/CLSI guidelines, using ampicillin, gentamicin, vancomycin, ciprofloxacin, erythromycin, tetracycline, chloramphenicol and imipenem. None of the other antimicrobial agents tested had a standardized breakpoint for Listeria sp, so the breakpoints established for Staphylococcus sp were used ${ }^{5}$.

\section{PCR-REA analysis}

The procedure described was based on the method by Ericsson et $\mathrm{al}^{6}$, which consists of amplification of a $2,916 \mathrm{bp}$ fragment containing parts of the inlA and inlB genes, which have been correlated with virulence of $L$. monocytogenes, and on further cleavage of the DNA fragment using the restriction endonuclease AluI. PCR was performed using the primers FD (5'CGACAACATTTAGTGAACCGTG3') and FN (5' GCTGCTTTCGTCCAACCAATGAA 3'), synthesized by Invitrogen Brazil, Ltd. The samples were analyzed by means of gel electrophoresis in $2 \%$ agarose stained with ethidium bromide $(0.5 \mu \mathrm{g} / \mathrm{ml})$. They were then viewed under UV transillumination and photographed using Kodak Digital Science ${ }^{\mathrm{TM}}$ DC120.

\section{RAPD analysis}

The two primers used in this study (UBC127 and UBC155) were designed in accordance with Farber \& Addison ${ }^{7}$. All PCR amplification was performed in a final volume of $25 \mu \mathrm{l}$ containing $1.5 \mathrm{mM}$ of $\mathrm{MgCl}_{2}, 0.2 \mathrm{mM}$ of each dNTP, $1 \mathrm{mM}$ of each primer and 1.25U of Taq DNA polymerase. A thermal cycler (MJ Research, Inc.; PTC-100) was used for the PCR reaction. The cycling parameters used were: one cycle at $94^{\circ} \mathrm{C}$ for 2 min followed by 35 cycles at $94^{\circ} \mathrm{C}$ for $1 \mathrm{~min}, 35^{\circ} \mathrm{C}$ for $1 \mathrm{~min}$ and $72^{\circ} \mathrm{C}$ for $2.5 \mathrm{~min}$, with a final extension of $5 \mathrm{~min}$ at $72^{\circ} \mathrm{C}$. The PCR products were analyzed and photographed as described above. The reproduction of RAPD was assessed by carrying out least three independent trials.

\section{Data analysis}

The results obtained from the RAPD analysis were examined using the SPSS software. The similarity between isolates was calculated by means of the simple association coefficient and the grouping analysis by means of UPGMA (unweighted pair group method using average). The presence or absence of bands generated by RAPD was considered to be an alternative characteristic, and it was coded as 1 or 0 , respectively.

\section{RESULTS}

\section{Antibiotic susceptibility test}

None of the 19 L. monocytogenes strains analyzed were resistant to the antimicrobials tested and only one of the isolates (A49) showed reduced susceptibility to ciprofloxacin antimicrobials.

\section{PCR-REA analysis}

The DNA fragment of 2,916bp obtained from amplification of the genome of L. monocytogenes using the primers FD/FN that correspond the internal region of genes inl $A B$ was digested using the restriction endonuclease AluI. The product from DNA cleavage made it possible to divide the strains analyzed into three different profiles. Most of the strains ${ }^{8}$ presented a 1 profile including the control strains $\mathrm{A} 51$ and $\mathrm{A} 56^{8}$. The $\mathrm{p} 2$ profile appeared in only one of the strains studied (A45) and the $\mathrm{p} 3$ profile was observed in the control strain ATCC7645 and strain A46 (Figure 1).

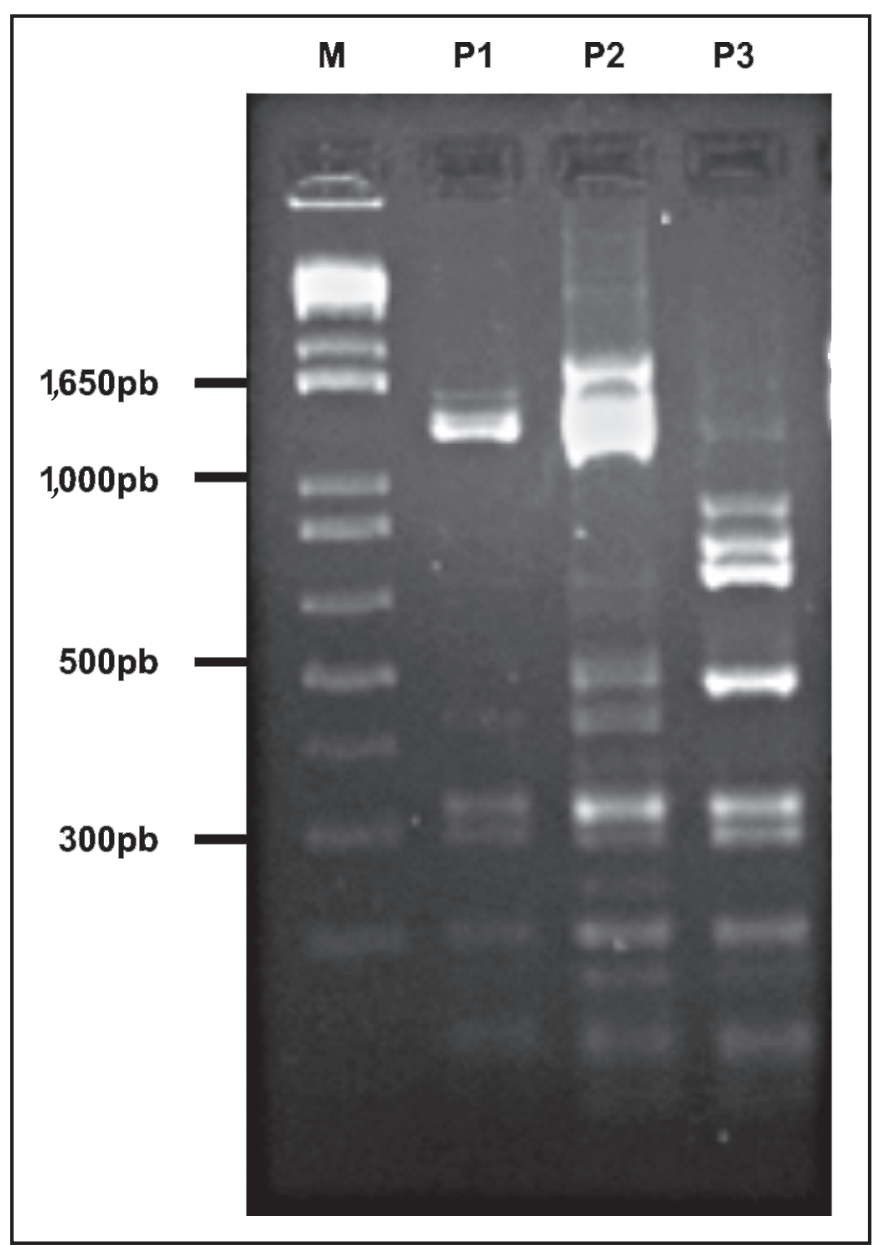

FIGURE 1 - PCR-REA profiles of L. monocytogenes from cleavage with restriction endonuclease $\mathrm{AluI}$. M: molecular weight - Kb ladder, p1: profile 1, p2: profile 2, p3: profile 3.

\section{RAPD analysis}

The UBC 127 primer produced three to five DNA bands with a molecular size between $450 \mathrm{bp}$ and $2500 \mathrm{bp}$ (Figure 2). The profiles of the UBC 127 primer are shown in a dendrogram (Figure 3). The strains of L. monocytogenes that were studied could be divided into three main clusters, with a similarity level around 0.74 . The first cluster included all the strains with serovars $1 / 2 b, 4 c$ and $4 b$, which were divided into three subgroups. The second one included only the two strains of L. monocytogenes isolated from dairy products with serovar 1/2a (A54 and A55). The third cluster separated the two control strains ATCC 7645 and A56, both with serovar 1/2a. It was also observed that the band for the highest molecular size $(2.5 \mathrm{~Kb})$ was reproduced in all the isolates from dairy products except in strain A39, while the molecular band of $1.5 \mathrm{~Kb}$ size was reproduced 


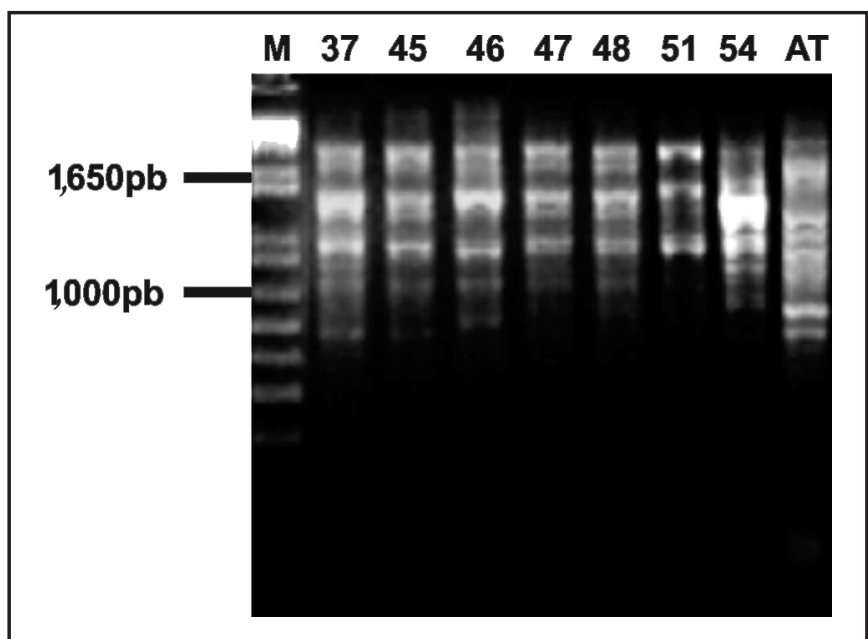

FIGURE 2 - RAPD typing of the L. monocytogenes strains, using the primer UBC 127. M: molecular weight - Kb ladder, 37: (A37), 45: (A45), 46: (A46), 47: (A47), 48: (A48), 51: (A51), 54: (A54) and AT: reference strain ATCC 7,645.

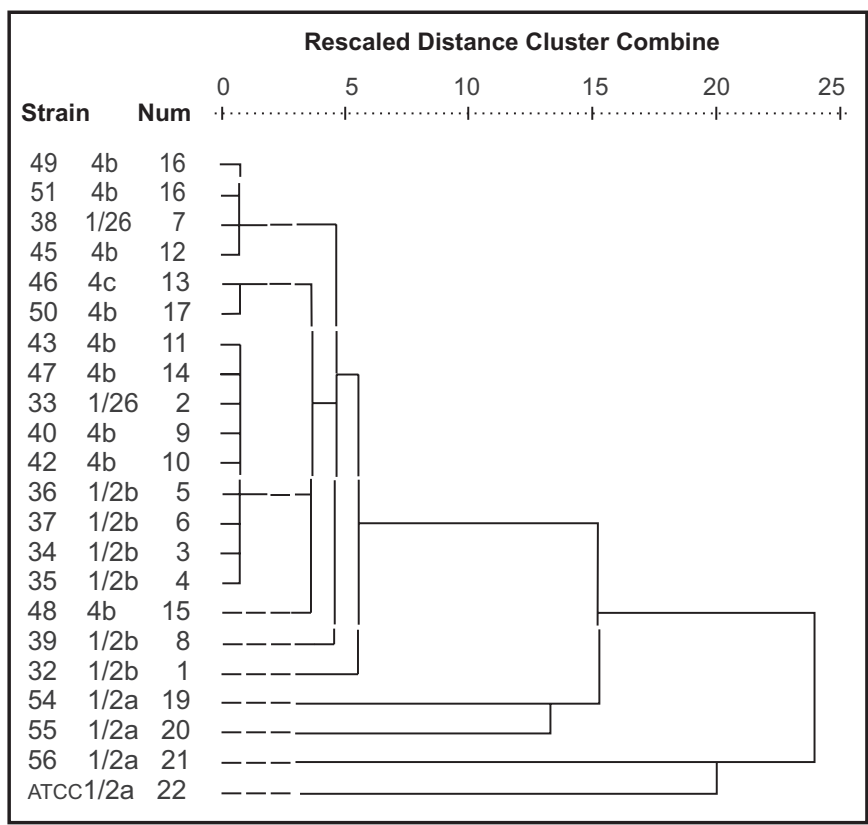

FIGURE 3 - Dendrogram of Listeria monocytogenes RAPD for strains isolated in southern Brazil and strains A51, A56 and ATCC 7,645, using the primer UBC127 and serovar discrimination.

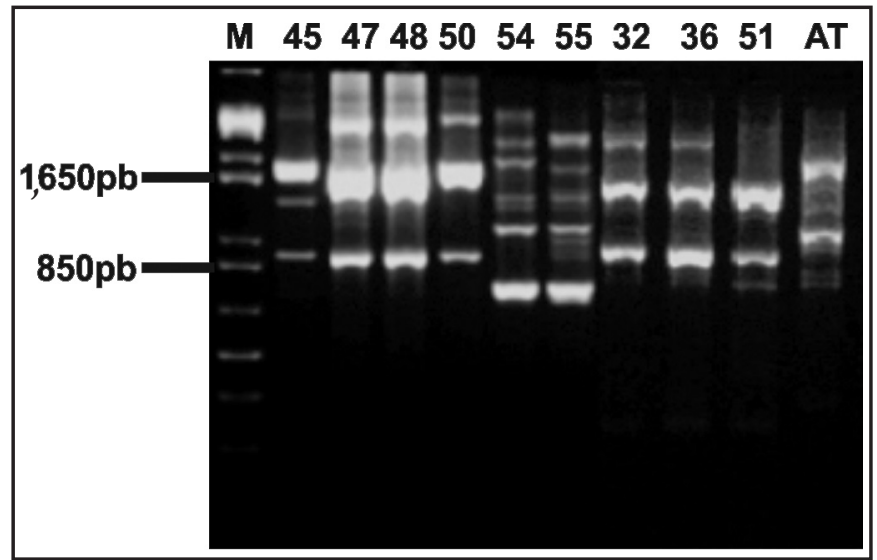

FIGURE 4 - RAPD typing of the L. monocytogenes strains, using the primer UBC 155. M: molecular weight - Kb ladder, 45: (A45), 47: (A47), 48: (A48), 50: (A50), 54: (A54), 55: (A55), 32:(A32), 36:(A36), 51:(A51), and AT; reference strain ATCC 7,645. in most of the strains of dairy products that were isolated, except in $1 / 2$ a serovars. The UBC 155 primer produced three to six DNA bands with molecular sizes of 250bp to 4,250bp (Figure 4). The profiles of the UBC 155 primer are shown in a dendrogram (Figure 5). The strains analyzed were divided into 3 main groups with a similarity level around 0.75 . The first cluster involved all the strains of L. monocytogenes serovars $1 / 2 b$, $4 b$ and $4 c$; this cluster could be further divided into four subgroups. The second group was formed by strains A54 and A55 of serovar 1/2a, isolated from dairy products in southern Brazil, and strain A56 isolated in Canada. ATCC 7,645 represented the third cluster.

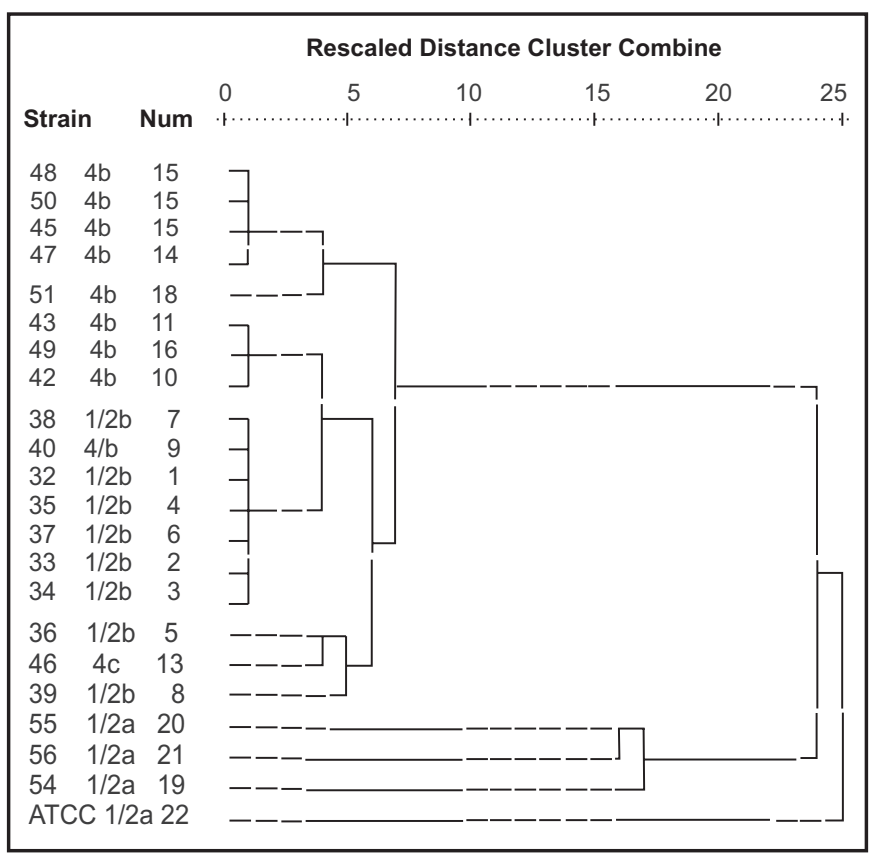

FIGURE 5 - Dendrogram of Listeria monocytogenes RAPD for strains isolated in southern Brazil and strains A51, A55 and ATCC 7,645, using the primer UBC 155 and serovar discrimination.

\section{DIsCusSION}

Listeriosis is an important and severe disease caused by the L. monocytogenes microorganism, in which the main source of disease transmission is ingestion of contaminated food, especially dairy products, which have been responsible for outbreaks of listeriosis ${ }^{1}$. In Brazil, there is a lack of information on listeriosis, particularly because there are no official statistics about the disease, given that its notification is not compulsory. There is no reporting of outbreaks; rather, only isolated cases are noted ${ }^{9}$.

The treatment chosen for listeriosis is the administration of penicillin or ampicillin associated with an aminoglycoside, usually gentamicin. For patients who are allergic to penicillin, the treatment can be administered successfully using a combination of vancomycin and an aminoglycoside or sulfamethoxazole-trimethoprim (TMP-SMX), in association with rifampicin. The use of cephalosporin is not suggested because strains of L. monocytogenes are generally resistant to those antimicrobials ${ }^{10}$. The incidence of resistance among isolates from clinical samples and food continues to be low. However, the emergence of resistant strains is being described in many studies ${ }^{11}{ }^{12}$. In 1988, the first strain of multi-resistant L. monocytogenes was isolated from human clinical material in France. The resistance was the result of plasmidial transfer, which was believed to have originated from 
enterococci or streptococci ${ }^{13}$. In Brazil, a study conducted on 13 samples of L. monocytogenes that had been isolated from 12 clinical cases of listeriosis in the south-western region of São Paulo, between January 1995 and May 2005, showed that none of the clinical isolates presented resistance to the antimicrobial that was tested, except for seven strains that presented reduced sensitivity to sulfamethoxazole ${ }^{14}$. In the present study, resistance was hardly ever found among the L. monocytogenes strains isolated from dairy products: only the strain A49 presented intermediate susceptibility to ciprofloxacin antimicrobials. The results presented in this study show that the strains isolated in this region are still susceptible to the antibiotics commonly used in hospitals for treating listeriosis.

The inlA and inlB genes have an essential role in the virulence of L. monocytogenes, through coding for two proteins found on the cell surface that are related to the invasion of epithelial cells ${ }^{15}$. Different authors have discriminated between L. monocytogenes strains, even in the same serovar, through using PCR-REA, based on the polymorphism that exists within the inlA and inlB genes, using the restriction enzyme AluI. In a study carried out on 133 strains of L. monocytogenes serovar $4 \mathrm{~b}$, isolated from food, animals, humans and the environment, it was possible to categorize the strains into two groups, group I containing 37 strains and group II containing 96 strains $^{6}$. Another analysis applying the same technique to 287 isolates of serovars $1 / 2 \mathrm{a}, 3 \mathrm{a}, 1 / 2 \mathrm{c}$ and $3 \mathrm{c}$ put the isolates into two clusters ${ }^{16}$. In the present study, using the abovementioned technique to analyze 19 strains isolated from dairy products, three profiles were found through using restriction endonuclease $A l u \mathrm{I}$ : $\mathrm{p} 1$, containing 17 strains of serovars $1 / 2 \mathrm{a}, 1 / 2 \mathrm{~b}$ and $4 \mathrm{~b}$; $\mathrm{p} 2$, containing one strain (A45) of serovar $4 \mathrm{~b}$; and p3, containing one strain (A46) of serovar 4c and ATCC 7645. This result shows the low degree of polymorphism in the inlA and inlB regions, which has already been shown in previous studies ${ }^{6,16,17}$. This has also already been observed in other genic regions associated with virulence of L. monocytogenes, such as the $m p l, p r f A$ and iap genes ${ }^{8,18}$.

RAPD is considered to be an easy and quick intra-species technique, with a good capacity for differentiation ${ }^{7,19}$. RAPD has been used in several pieces of research to characterize strains of L. monocytogenes, observing their origins, contamination focus and epidemiology $y^{16,17,20}$. The primers used in the present study (UBC127 and UBC 155) presented good power of discrimination among the strains that were isolated. It was observed that the strains were separated into three main clusters: cluster I, containing serovars $1 / 2 \mathrm{~b}, 4 \mathrm{~b}$ and $4 \mathrm{c}$; and clusters II and III, containing serovar $1 / 2 \mathrm{a}$ (A54, A55) as well as the strain control. Since RAPD analysis is based on the use of random-sequence primers, these results point towards a high level of polymorphism, particularly among serovars $1 / 2 \mathrm{a}$ and $1 / 2 \mathrm{~b}$. This had already been observed in research that used the primers UBC155, UBC156 and UBC157 in the RAPD technique, to analyze 39 strains of $L$. monocytogenes that were isolated from raw milk, smoked meat and chicken carcasses, belonging to serovars $1 / 2 \mathrm{a}, 4 \mathrm{a}, 1 / 2 \mathrm{~b}, 3 \mathrm{~b}$ and $4 \mathrm{~b}^{17}$. The primers used in the present study had already been applied ${ }^{19}$ to trace L. monocytogenes contamination in a shrimp-processing factory, from which it was concluded that this technique could be used to trace the contamination by L. monocytogenes in food-processing factories.

In conclusion, the results presented in this study show that strains isolated in this region remain susceptible to antibiotics commonly used in hospitals for treating listeriosis. The diverse serovars presented in strains of L. monocytogenes isolated from dairy products in southern Brazil showed a low degree of molecular diversity among the strains analyzed, and the main differences occurred between the strains belonging to serovar $1 / 2 \mathrm{a}$ and the other serovars studied.

\section{CONFLICT OF INTEREST}

The authors declare that there is no conflict of interest.

\section{REFERENCES}

1. Gandhi M, Chikindas ML. Listeria: A foodborne pathogen that knows how to survive. Int J Food Microbiol 2007; 113:1-15.

2. White DG, Zhao S, Simjee S, Wagner DD, McDermott PF. Antimicrobial resistance of foodborne pathogens. Microbes Infect 2002; 4:405-412.

3. Hofer E, Ribeiro R, Feitosa DP. Species and serovars of the Genus Listeria isolated from different sources in Brazil from 1971 to1997. Mem Inst Oswaldo Cruz 2000; 95:615-620.

4. Torres K, Poutou R, Carrascal A, Sierra S, Mercado M. Validación de PCR para detección de Listeria monocytogenes en carnes crudas de res y pollo. MVZ-Córdoba. 2004; 9:414-427.

5. National Committee for Clinical Laboratory Standards/CLSI. Performance Standards for Antimicrobial Susceptibility Testing; Twelfth Informational supplemente. CLSI/NCCLS document M100 - S12. CLSI, Wayne, PA, USA, 2002

6. Ericsson H, Stalhandske P, Danielsson-Tham ML, Bannerman E, Bille J Jacquet C, et al. Division of Listeria monocytogenes Serovar $4 \mathrm{~b}$ Strains into Two Groups by PCR and Restriction Enzyme Analysis. Appl Environ Microbiol 1995; 61:3872-3874.

7. Farber JM, Addison CJ. RAPD typing for distinguishing species and strains in the genus Listeria. J Appl Bacteriol 1994; 77:242-250.

8. Vines A, Reeves MW, Hunter S, Swaminathan B. Restriction fragment length polymorphism in four virulence-associated genes of Listeria monocytogenes. Res Microbiol 1992; 143:281-294.

9. Hofer E, Nascimento RS, Oliveira MA. Meningite por Listeria monocytogenes. Relato de casos em pacientes do Distrito Federal. Rev Soc Brasil Med Trop 1998 31:173-177.

10. Swaminathan B, Gerner-Smidt P. The epidemiology of human listeriosis. Microbes Infect 2007; 9:1236-1243.

11. Arslan S, Özdemir F. Prevalence and antimicrobial resistance of Listeria spp In homemade white cheese. Food Control 2008; 19:360-363.

12. Srinivasan V, Nam HM, Nguyen LT, Tamilselvam B, Murinda SE, Oliver SP. Prevalence of antimicrobial resistance genes in Listeria monocytogenes isolated from dairy farms. Foodborne Pathog Dis 2005; 2:201-211.

13. Hansen JM, Gerner-Smidt P, Bruun B. Antibiotic susceptibility of Listeria monocytogenes in Denmark 1958-2001. APMIS 2005; 113:31-36.

14. Lemes-Marques EG, Cruz CD, Destro MT. Pheno and genotypic characterization of Listeria monocytogenes clinical isolates from the southwestern region of the state of São Paulo, Brazil. Braz J Microbiol 2007; 38:287-292.

15. Hamon M, Bierne H, Cossart P. Listeria monocytogenes: a multifaceted model. Nat Rev Microbiol 2006; 4:423-434.

16. Giovannacci L, Ragimbeau C, Queguiner S, Salvat G, Vendeuvre J-L, Carlier V, et al. Listeria monocytogenes in pork slaughtering and cutting plants use of RAPD, PFGE and PCR-REA for tracing and molecular epidemiology. Int J Food Microbiol 1999; 53:127-140.

17. Cabrita P, Correia S, Ferreira-Dias S, Brito L. Genetic characterization of Listeria monocytogenes food isolates and pathogenic potential within serovars $1 / 2 \mathrm{a}$ and 1/2b. Syst Appl Microbiol 2004; 27:454-461.

18. Mello JF, Einsfeldt K, Frazzon APG, Costa M, Frazzon J. Molecular analysis of the iap gene of Listeria monocytogenes isolated from cheeses in Rio Grande do Sul, Brazil. Braz J Microbiol 2008; 39:169-172.

19. Destro MT, Leitão MFF, Farber JM. Use of molecular typing methods to trace the dissemination of Listeria monocytogenes in a shrimp processing plant. Appl Environ Microbiol 1996; 62:705-711.

20. Aguado V, Vitas AI, García-Jalón I. Characterizaton of Listeria monocytogenes and Listeria innocua from a vegetable processing plant by RAPD and REA Int J of Food Microbiol 2004; 90:341-347. 